\title{
MARKET SEGMENTATION OF VISITORS AT THREE SELECTED ARTS FESTIVALS IN SOUTH AFRICA
}

\author{
V Pissoort \& M Saayman, Institute of Tourism and Leisure Studies, Vaal University of Technology, \\ Potchefstroom, South Africa
}

Purpose: The purpose of this article is to examine the market segmentation of visitors at three Arts Festivals in South Africa. The Arts Festivals were Innibos, Oppikoppi and Volksblad.

Problem investigated: The literature review clearly shows that, in order for marketers of festivals to use scarce resources effectively and efficiently, it is paramount to do market segmentation. The advantages of market segmentation lie in an increase in visitor numbers, better image, and by creating a competitive advantage to name but a few.

Method of research: The research was conducted by means of structured questionnaires at the three arts festivals. The data was used to compile a profile of each Festival. The significance of the correlation between the three Festivals and their profiles were tested by using effect sizes and Chi-square. A sample size of 452 questionnaires for Volksblad, 573 questionnaires for Innibos and 201 for Oppikoppi was used.

Findings: The results show that the visitor profile variables that are significant for market segmentation purposes include: language; the province in which Festival attendees reside; days spent at the Festival; and the size of the travelling group. These results confirmed but also contradicted a number of similar studies conducted. The results also clearly showed the different profiles of each of the three arts festivals.

Value of research: This was the first time such research was undertaken at smaller Arts Festivals in South Africa and is useful for planning and marketing purposes.

Conclusion: Due to the increase in the number of festivals and events in South Africa as well as competition in general, marketers and organisers of these events and festivals are required to understand and target the right markets. Hence, this type of research is important and necessitates marketers and event organisers to follow a more scientific approach.

Key words and phrases: Festivals, arts, attractions, marketing, segmentation and events.

\section{INTRODUCTION}

Since the dawn of history, Festivals and events have been important features of people's lives. Festivals and events evolved as celebrations to mark high points in the Christian calendar, for example, Saints' days and the like (Van Zyl, 2005:53). Arts Festivals have become important in the South African context because of a growing need among the broader public for various forms of art to accommodate the diversity of cultures within the borders of the country. Arts Festivals are generally important for a number of reasons, namely: to sustain different forms of art; to contribute to the livelihood of artists; to stimulate the growth of regional and local economies; to promote specific destinations; and to create specific images of these destinations (Saayman, Slabbert \& Saayman, 2005:7).

According to Gursoy, Kim and Uysal (2004:172), Festivals and special events have, in recent years, become one of the fastest growing tourism attractions. Therefore, it is not surprising to see that the number of conceptual and empirical studies on Festivals and special events has increased rapidly (Hughes, 2000:2). Festivals and other events have the ability to spread tourism both geographically and seasonally. Special events allow a region or community to celebrate its uniqueness, to promote itself, develop local pride and enhance its economic well-being (Mclntosh, Goeldner \& Ritchie, 1995:157).

Currently, at least 211 annual Festivals take place in South Africa (Visser, 2005:165). Visser (2005:166) states that $28 \%$ of the 211 Festivals focus on performing and visual arts and, more generally, on a 
combination thereof. Since 1995, Festivals seem to have taken root in every community in need of economic or social upliftment. Some towns host Festivals in order to emphasise their unique character, and to share their customs, natural environments and local produce with visitors (Kitshoff, 2004: 65 and Visser, 2005:155). Festivals form part of tourist attractions, which are arguably the most important component in the tourism system. Tourist attractions are the main reason for tourist trips and so form the core of the tourism product. Without attractions to draw the tourists, there would be no need for other tourism services. Swarbrooke (2002:1) states that tourism as such would not exist if it were not for attractions.

One important issue concerning market segmentation is how best to subdivide travel markets (Jang, Morrison \& O'Leary, 2002:367). Segmentation is important because it can assist the marketing team to target the best segment for the attraction. With segmentation information, the needs and wants of the Festival attendees can be specified and provided.

The purpose of this article is to undertake market segmentation research of visitors to selected Arts Festivals in South Africa. In order to achieve this goal, the paper is structured as follows: an introduction precedes the literature review, which is then followed by a description of the method of research and the results of such research. Finally, conclusions are drawn and recommendations are made.

\section{LITERATURE REVIEW}

Market segmentation is the process of subdividing customers into different groups, or segments, within which customers with similar characteristics have similar needs. By doing this, each one can be targeted and reached with a distinct marketing mix to increase the number of tourists and the resulting sales (McDonald \& Dunbar, 1995:10). In other words, market segmentation is the way in which tourism companies divide a market into smaller, more clearly defined groups that share similar needs, wants, and characteristics (Lancaster \& Reynolds, 1999:8; Kotler, 2003:549 and George, 2004:125).

Segmentation is important in order for a destination to target the right kind of visitor. The marketing of events and the marketing of tourism offerings have an essential difference. The difference lies in the fact that events are usually an annual occasion. This implies that organisers in most cases have only one chance per year to be successful in their marketing activities. Tourism offerings, on the other hand, are there to be enjoyed all year and so different marketing approaches can be used. Lee, Lee and Wicks (2004:62) emphasise the importance of analysing visitors' motives for attending Festivals and events. Identifying such motives is therefore a prerequisite for planning and marketing event programmes effectively. Segmentation can assist event and Festival planners to carry out effective marketing for the right target group (Saayman \& Saayman, 2006).

Based on findings by Bennet and Strydom, (2001:64); Dibb and Simkin, (2001:230); McDonald and Dunbar, (1995:16); Saayman, (2002:85); George, (2004:135) and Marx et al. (1998:535), the benefits of segmenting a market can be identified as follows:

- Market segmentation allows marketers to concentrate on consumer needs and wants;

- Market segmentation helps marketers to develop an effective marketing mix;

- Market segmentation enables more efficient market positioning;

- Recognising customers' differences is key to successful marketing, as it can lead to a closer matching of customers' needs with the products and services of the company;

- Segmentation can lead to niche marketing, where applicable. The organisation could meet most or all of the needs of customers in that niche segment;

- Segmentation can lead to concentration of resources in markets where competitive advantages are great and returns are high;

- Through segmentation, a competitive advantage may be gained by having a different approach than that of the market competition; 
- By means of segmentation, the organisation can be marketed as a specialist in the selected market segments with a better comprehension of customers' needs; thus giving the products/services a perceived advantage over the competitors' products;

- Segmentation promotes new product ideas;

- A long-term relationship can be established with a specific customer group

The division (or segmentation) of the market can be carried out in a number of ways. Depending on the situation, a marketer may experiment with a variety of segmentation variables (Burke \& Resnick, 1999:41). These could include geographic, socio-demographic, psychographic and/or behavioural characteristics (Slabbert 2002:2). A brief description of these variables is shown in Table 1 below.

\section{Table 1: Segmentation variables}

\begin{tabular}{|c|c|c|}
\hline Variables of segmentation & Definition of variable & Sub-categories \\
\hline Geographic & $\begin{array}{l}\text { Relating to geographical } \\
\text { distribution }\end{array}$ & \\
\hline Demographic & $\begin{array}{l}\text { The study of the } \\
\text { structure of human } \\
\text { populations }\end{array}$ & $\begin{array}{ll}- & \text { Gender segment } \\
- & \text { Income segment } \\
- & \text { Age and family life cycle } \\
\end{array}$ \\
\hline Psychographic & $\begin{array}{l}\text { A graphic } \\
\text { representation or chart } \\
\text { of the personality traits } \\
\text { of an individual or group }\end{array}$ & $\begin{array}{ll}\text { - } & \text { Personality } \\
\text { - } & \text { Lifestyle }\end{array}$ \\
\hline Social class & $\begin{array}{l}\text { A term describing the } \\
\text { standing of an individual } \\
\text { in the social hierarchy }\end{array}$ & \\
\hline Behavioural segmentation & $\begin{array}{l}\text { Behavioural } \\
\text { segmentation divides } \\
\text { the population on } \\
\text { grounds of their actions }\end{array}$ & $\begin{array}{ll}\text { - } & \text { Desire for benefits } \\
\text { - } & \text { Expenditure } \\
\text { - } & \text { User status } \\
\text { - } & \text { Attitudes towards offerings } \\
\text { - } & \text { Loyalty } \\
\text { Buyer readiness }\end{array}$ \\
\hline Socio-economic & $\begin{array}{l}\text { Describes the impact of } \\
\text { visitors on the host } \\
\text { community and their } \\
\text { economy }\end{array}$ & \\
\hline Purpose of travel & $\begin{array}{l}\text { Motivation for the } \\
\text { journey }\end{array}$ & \\
\hline
\end{tabular}

(Burke \& Resnick, 1999:41; Lubbe, 2000:77; Saayman, 2002:94; George, 2004:126; Kotler \& Armstrong, 2004:240 and Lamb et al., 2004:168).

Examples of segmentation studies include: Mok and Iverson (2000) who used expenditure, Van Wyk (2004) personal income, Galloway (2002) psychographic segmentation, Koc and Altinay (2006) seasonality in monthly spending per person, Bigne and Andreu (2004), emotions, Thrane (1997) valuables and Juaneda and Sastre (1999) demographics as variables. Shaw and Leggat (2003) used country profile and Saayman and Uys (2003) used spectators at a One-Day International cricket match.

With regard to Arts Festivals, the following studies were previously conducted. Hauptfleisch (2001) and Silva (1998) researched Klein Karoo National Arts Festival (KKNK), Grahamstown Arts Festival studies were undertaken by Snowball and Willis (2006:43). Williams (1997); Van Zyl (2002), Van Heerden (2002), Van Zyl and Botha (2003) used Aardklop as a topic. Van Niekerk, Saayman and Saayman (2004 and 2005) researched the economic impact of Innibos Arts Festival. In addition to these, Strydom, Saayman and Saayman (2007) completed an economic analysis of Volksblad Arts Festival. However, Visser states 
that research and published research of Festivals in South Africa has been neglected by researchers (2005:160). Snowball and Willis (2006:43) add that more detailed information (research) will help organisers to allocate resources more effectively. Little research has been carried out on smaller Arts Festivals in South Africa one reason why smaller Festivals are neglected in terms of research could be because they do not get as much exposure, and are regarded as being overshadowed by the bigger Festivals such as Aardklop, KKNK and Grahamstown. Nevertheless, Saayman and Saayman (2004) confirmed that, from an economic point of view, these Festivals provide a significant economic injection to the local community. Hence, this research will attempt to use visitor profile variables at the Volksblad, Innibos and Oppikoppi Festivals to define the different profiles of each of the Festivals.

\section{METHODOLOGY}

Based on the estimated visitor numbers of the Festivals, a sample size of 400 questionnaires for Volksblad, 400 questionnaires for Innibos and 200 for Oppikoppi was anticipated. According to Cooper and Emory, (1995:207); as well as Krejcie and Morgan (1970:608), for a population of 100000 the recommended sample size is 384 .

A brief background of each Festival reveals the following:

Innibos is held annually at Nelspruit during June. The Festival was three years old in 2007 (Innibos, 2005:1) and attracts approximately 30000 visitors annually.

Oppikoppi is held in Northam during August. The Festival attracts approximately 10000 visitors (Oppikoppi, 2005) and will have its $13^{\text {th }}$ birthday in 2007.

The Volksblad Arts Festival takes place annually in Bloemfontein. It attracts approximately 30000 visitors and is 6 years old (Volksbladfees, 2005).

The variables used in the questionnaire were:

- age distribution,

- language,

- marital status,

- occupation,

- travel group size,

- nights spent,

- province of origin,

- expenditure,

- type of accommodation used,

- other Festivals attended during the year,

- transport,

- attendance of free shows, and

- main reason for visiting the Festival.

These variables were chosen because they gave sufficient information to draw up profiles of the various Festivals.

Data collection was undertaken by field workers who distributed questionnaires to the festinos at the Festivals. The research instrument (questionnaire) was similar to that used in studies conducted at other Arts Festivals in South Africa, for example, those by Van Heerden (2002) and by Saayman and Saayman (2004).

As recommended by Walpole and Goodwin (2000), the surveys were conducted amongst tourists to estimate the demand of products and services during three Arts Festivals. A destination-based survey 
was undertaken, where interviews were held on-site during the event. Different sites at the Festivals were chosen to limit response bias towards any specific group of Festival attendants. The surveys followed a non-probability sampling method, thus respondents were chosen randomly and the survey was conducted throughout the duration of the Festival. At each of the three Festivals, questionnaires were interviewer-administered The questionnaires were distributed throughout the duration of the three Festivals. The questionnaires were handed out in increasing increments each day in order to ensure that the sample population was a true reflection of Festival attendees. Day one $=10 \%$, Day $2=20 \%$, Day $3=$ $30 \%$ of the questionnaires and Day $4=40 \%$ of the questionnaires were distributed. At Innibos, 573 reliable questionnaires were collected, at Oppikoppi, 201 and at Volksblad, 452.

The programmes Microsoft Windows Excel and the SAS statistical package (version 9) were used for the execution of the data analysis. The raw data was first captured in Excel and then the SAS program was applied.

Once a profile exists, comparisons can be made to determine whether these three Festivals attract the same type of tourist. When this too has been determined, comparisons can be made how this profile varies (or not) from other established Festivals. An ANOVA-analysis (analyses of variance) that measures the variance that exists between groups and Tukey HSD (honestly significantly difference test) was determined. Furthermore, a two-way relationship was done in order to determine if certain variables have a large impact on a Festival. A relationship with $w \geq 0.5$ is considered to be practically significant.

\section{RESULTS}

Firstly, the tourist profile of each Festival is reviewed. Secondly, the relationship between the Festival and various variables will be discussed.

\section{Tourist Profiles}

With all the data gathered from the Festivals and the results thereof, an average profile of festinos to the three Festivals was determined (Table 2).

Table 2: Profile of festinos at the selected Festivals

\begin{tabular}{|l|l|l|l|}
\hline VARIABLE & INNIBOS & VOLKSBLAD & OPPIKOPPI \\
\hline AGE DISTRIBUTION & 23 & 30 & 22 \\
\hline LANGUAGE & Afrikaans & Afrikaans & Afrikaans \\
\hline MARITAL STATUS & Married & Married & Not married \\
\hline OCCUPATION & $\begin{array}{l}\text { Professional, } \\
\text { manager }\end{array}$ & $\begin{array}{l}\text { Professional, } \\
\text { student }\end{array}$ & Student \\
\hline $\begin{array}{l}\text { TRAVEL GROUP } \\
\text { SIZE }\end{array}$ & 5 & 2 & $1-5$ \\
\hline NIGHTS SPENT & 4 & 5 & 4 \\
\hline $\begin{array}{l}\text { PROVINCE } \\
\text { DISTRIBUTION }\end{array}$ & Mpumalanga & Free State & Gauteng \\
\hline EXPENDITURE & R1062,11 & R538,07 & R1669,95 \\
\hline $\begin{array}{l}\text { ACCOMMODATION } \\
\text { OTHER FESTIVALS }\end{array}$ & $\begin{array}{l}\text { Friends amily } \\
\text { fardklop }\end{array}$ & Friends and family & Camp site provided \\
\hline ATTENDED & KKNK & Aardklop \\
\hline TRANSPORT \\
\hline $\begin{array}{l}\text { ATTENDANCE OF } \\
\text { FREE SHOWS }\end{array}$ & $77 \%$ & Sedan & Sedan \\
\hline $\begin{array}{l}\text { MAIN REASON FOR } \\
\text { VISIT }\end{array}$ & Sociable & Sociable & Sociable \\
\hline
\end{tabular}


From Table 2, it is evident that most festinos at each of the Festivals were Afrikaans-speaking. The host province of each Festival generated the greatest number of festinos to the Festival. Festinos spent more at Oppikoppi than either of the other Festivals. The main reason for attending the Festivals was to socialise, and to meet new people. Free shows attended were about the same for Volksblad and Innibos. The question was not applicable for Oppikoppi because the entrance fee covered all the shows for the duration of the Festival. The main differences between the three Festivals were that Oppikoppi was attended by mainly students, and that Volksblad and Innibos were mainly attended by families. The festinos at Oppikoppi also spend more money on food and drink, and camping at the venue. Volksblad and Innibos attract mostly locals, and other festinos tend to stay with friends and family.

\section{Relationship between Variables}

In this section, the relationship between the three Festivals and the demographical data was determined. The statistical significance of such relationships is determined with the Chi-square test but one actually wants to know whether the relationship is large enough to be important. This will indicate if there is a relationship between the variables of a certain Festival, and finally will assist with drawing up a profile of the Festival.

In this case the effect size is given by $w=\sqrt{ }\left(x^{2} / n\right)$, where $x^{2}$ is the usual Chi-square statistic for the contingency table and $n$ is the sample size (Steyn, 2000). In the special case of a $2 \times 2$ table, the effect size $(w)$ is given by phi $(\Phi)$ coefficient. Note that the effect size is again independent of sample size. Ellis and Steyn (2003:51) give the following guidelines for the interpretation of the effect size in the current case:

(a) small effect: $w=0.1$, (b) medium effect: $w=0.3$, (c) large effect: $w=0.5$.

A relationship with $w \geq 0.5$ is considered practically significant.

The practical significance of results is not only important when the results of population data are reported but also will enable comment on the practical significance of statistical significant results in the case of random samples from populations (Ellis \& Steyn, 2003:53).

Another method was used to analyse the data for travel group size and days spent at Festivals. The ANOVA table measures the differences in average. The Tukey HSD (Honestly Significant Different) test is done where the Cohen $d$ is calculated (www.blackwell-synergy.com, 22 November 2006). Cohen (1988) gives the following guidelines for the interpretation of the effect size in the current case:

Cohen $\mathrm{d}=\frac{\bar{x}_{1}-\bar{x}_{2}}{\sqrt{M S E}}$

If $d=0.2$ it is a small effect

If $d=0.5$ it is a medium effect

If $d=0.8$ it is a large effect

Data with $d \geq 0.8$ is considered as practically significant.

\section{Relationship between Gender and Festivals}

Table 3 indicates the relationship between gender and the different Festivals. 
Table 3: Gender and Festivals

\begin{tabular}{|c|c|c|c|c|}
\hline \multirow[t]{2}{*}{$\overline{\text { Festival }}$} & & \multicolumn{2}{|c|}{ Gender } & \multirow[t]{2}{*}{ Total } \\
\hline & & Male & Female & \\
\hline Innibos & $\begin{array}{l}\text { Frequency } \\
\text { Percent } \\
\text { Row Pct } \\
\text { Col Pct }\end{array}$ & $\begin{array}{l}237 \\
19.33 \\
41.36 \\
44.30 \\
\end{array}$ & $\begin{array}{l}336 \\
27.41 \\
58.64 \\
48.63 \\
\end{array}$ & $\begin{array}{l}573 \\
46.74\end{array}$ \\
\hline Oppikoppi & $\begin{array}{l}\text { Frequency } \\
\text { Percent } \\
\text { Row Pct } \\
\text { Col Pct }\end{array}$ & $\begin{array}{l}116 \\
9.46 \\
57.71 \\
21.68 \\
\end{array}$ & $\begin{array}{l}85 \\
6.93 \\
42.29 \\
12.30\end{array}$ & $\begin{array}{l}201 \\
16.39\end{array}$ \\
\hline Volksblad & $\begin{array}{l}\text { Frequency } \\
\text { Percent } \\
\text { Row Pct } \\
\text { Col Pct }\end{array}$ & $\begin{array}{l}182 \\
14.85 \\
40.27 \\
34.04 \\
\end{array}$ & $\begin{array}{l}270 \\
22.02 \\
59.73 \\
39.07\end{array}$ & $\begin{array}{l}452 \\
36.87\end{array}$ \\
\hline Total & & $\begin{array}{l}535 \\
43.64\end{array}$ & $\begin{array}{l}691 \\
56.36\end{array}$ & $\begin{array}{l}1226 \\
100.00\end{array}$ \\
\hline
\end{tabular}

The phi coefficient $(0.12)$ indicates that there is a small effect, which means there is no significant relationship between Festivals and the gender of Festival attendees (Table 3). In research done (Optimum market-positioning models for South African Arts Festival scenarios) by Van Zyl (2005:211) the gender distribution for Aardklop, Grahamstown, and KKNK was similar. Hence, it can be concluded that the gender of festinos is not greatly significant.

\section{Relationship between Occupation and Festivals}

Table 4 gives an indication of the relationship between the Festivals and various occupations.

Table 4: Occupation and festivals

\begin{tabular}{|c|c|c|c|c|c|c|c|c|c|c|}
\hline \multirow[b]{2}{*}{ Festival } & \multicolumn{10}{|l|}{ Occupation } \\
\hline & & $\begin{array}{l}\text { Profes- } \\
\text { sional }\end{array}$ & $\begin{array}{l}\text { Mana- } \\
\text { ger }\end{array}$ & $\begin{array}{l}\text { Admin- } \\
\text { strative }\end{array}$ & $\begin{array}{l}\text { Technic } \\
\text { al }\end{array}$ & Sales & Farmer & $\begin{array}{l}\text { Studen } \\
\mathrm{t}\end{array}$ & Other & Total \\
\hline Innibos & $\begin{array}{l}\text { Frequency } \\
\text { Percent } \\
\text { Row Pct } \\
\text { Col Pct }\end{array}$ & $\begin{array}{l}74 \\
6.13 \\
13.31 \\
31.90\end{array}$ & $\begin{array}{l}75 \\
6.21 \\
13.49 \\
56.82 \\
\end{array}$ & $\begin{array}{l}49 \\
4.06 \\
8.81 \\
56.82 \\
\end{array}$ & $\begin{array}{l}15 \\
1.24 \\
2.70 \\
33.33 \\
\end{array}$ & $\begin{array}{l}44 \\
3.65 \\
7.91 \\
68.75 \\
\end{array}$ & $\begin{array}{l}11 \\
0.91 \\
1.98 \\
40.47 \\
\end{array}$ & $\begin{array}{l}73 \\
6.05 \\
13.13 \\
31.47 \\
\end{array}$ & $\begin{array}{l}215 \\
17.81 \\
38.64 \\
55.27\end{array}$ & $\begin{array}{l}556 \\
46.06\end{array}$ \\
\hline Oppikoppi & $\begin{array}{l}\text { Frequency } \\
\text { Percent } \\
\text { Row Pct } \\
\text { Col Pct }\end{array}$ & $\begin{array}{l}30 \\
2.46 \\
14.93 \\
12.93 \\
\end{array}$ & $\begin{array}{l}33 \\
2.73 \\
16.42 \\
25.00 \\
\end{array}$ & $\begin{array}{l}18 \\
1.49 \\
8.96 \\
20.93 \\
\end{array}$ & $\begin{array}{l}20 \\
1.66 \\
9.95 \\
44.44 \\
\end{array}$ & $\begin{array}{l}9 \\
0.75 \\
4.48 \\
14.06\end{array}$ & $\begin{array}{l}5 \\
0.41 \\
2.49 \\
18.52 \\
\end{array}$ & $\begin{array}{l}59 \\
4.89 \\
29.35 \\
25.43 \\
\end{array}$ & $\begin{array}{l}27 \\
2.24 \\
13.43 \\
6.94 \\
\end{array}$ & $\begin{array}{l}201 \\
16.65\end{array}$ \\
\hline Volksblad & $\begin{array}{l}\text { Frequency } \\
\text { Percent } \\
\text { Row Pct } \\
\text { Col Pct }\end{array}$ & $\begin{array}{l}128 \\
10.60 \\
28.44 \\
55.17 \\
\end{array}$ & $\begin{array}{l}24 \\
1.99 \\
5.33 \\
18.18 \\
\end{array}$ & $\begin{array}{l}19 \\
1.57 \\
4.22 \\
22.09\end{array}$ & $\begin{array}{l}10 \\
0.83 \\
2.22 \\
22.22 \\
\end{array}$ & $\begin{array}{l}11 \\
0.91 \\
2.44 \\
17.19 \\
\end{array}$ & $\begin{array}{l}11 \\
0.91 \\
2.44 \\
40.74\end{array}$ & $\begin{array}{l}100 \\
8.29 \\
22.22 \\
43.10 \\
\end{array}$ & $\begin{array}{l}147 \\
12.18 \\
32.67 \\
37.79 \\
\end{array}$ & $\begin{array}{l}450 \\
37.28\end{array}$ \\
\hline Total & & $\begin{array}{l}232 \\
19.22\end{array}$ & $\begin{array}{l}132 \\
10.94\end{array}$ & $\begin{array}{l}86 \\
7.13\end{array}$ & $\begin{array}{l}45 \\
3.73\end{array}$ & $\begin{array}{l}64 \\
5.30\end{array}$ & $\begin{array}{l}27 \\
2.24\end{array}$ & $\begin{array}{l}232 \\
19.22\end{array}$ & $\begin{array}{l}389 \\
32.33\end{array}$ & $\begin{array}{l}1207 \\
100.00\end{array}$ \\
\hline
\end{tabular}


According to Table 4 the phi coefficient of 0.35 indicates a medium effect. At Innibos the variable that is notably higher than the rest is the other occupation variable. This does not specify the type of occupation. At Oppikoppi, the student variable plays a large role and at Volksblad, the most significant variables are the other occupation, professional and student categories. This could be because the Festival is held at the University and because there are various academic institutions in the vicinity. The higher the income of attendees the more disposable income they have and the more they will spend (Lubbe, 2000:241).

\section{Relationship between Language and Festivals}

Table 5 shows the relationship between the Festivals and language of the attending visitor. The phi coefficient $(0.65)$ indicates that there is a significant relationship between the language that tourists speak and the Festivals they attend. A majority of attendees at each of the three Festivals are Afrikaans speaking. In other words, this variable is significant. This could be because the primary market of these Festivals is Afrikaans speaking people.

Table 5: Language and festivals

\begin{tabular}{|c|c|c|c|c|c|}
\hline \multirow[t]{2}{*}{ Festival } & & \multicolumn{3}{|l|}{ Language } & \multirow[t]{2}{*}{ Total } \\
\hline & & Afrikaans & English & Other & \\
\hline Innibos & $\begin{array}{l}\text { Frequency } \\
\text { Percent } \\
\text { Row Pct } \\
\text { Col Pct }\end{array}$ & $\begin{array}{l}477 \\
38.84 \\
82.81 \\
50.91\end{array}$ & $\begin{array}{l}75 \\
6.11 \\
13.02 \\
28.63\end{array}$ & $\begin{array}{l}24 \\
1.95 \\
4.17 \\
82.76 \\
\end{array}$ & $\begin{array}{l}576 \\
46.91\end{array}$ \\
\hline Oppikoppi & $\begin{array}{l}\text { Frequency } \\
\text { Percent } \\
\text { Row Pct } \\
\text { Col Pct }\end{array}$ & $\begin{array}{l}163 \\
13.27 \\
81.09 \\
62.21\end{array}$ & $\begin{array}{l}38 \\
3.09 \\
18.91 \\
4.09\end{array}$ & $\begin{array}{l}0 \\
0.00 \\
0.00 \\
0.00\end{array}$ & $\begin{array}{l}201 \\
16.37\end{array}$ \\
\hline Volksblad & $\begin{array}{l}\text { Frequency } \\
\text { Percent } \\
\text { Row Pct } \\
\text { Col Pct }\end{array}$ & $\begin{array}{l}422 \\
34.36 \\
93.57 \\
45.04\end{array}$ & $\begin{array}{l}24 \\
1.95 \\
5.32 \\
9.16\end{array}$ & $\begin{array}{l}5 \\
0.41 \\
1.11 \\
17.24\end{array}$ & $\begin{array}{l}451 \\
36.73\end{array}$ \\
\hline
\end{tabular}

\section{Relationship between Province and Festivals}

Table 6 shows the three Festivals and the relationship with the province of origin of the Festival attendants. The phi coefficient of 1.016 indicates that there is a significant relationship between the Festivals and province of origin of the festinos. Most of the tourists are from the same province in which the Festival is held. The two variables that play a large role at Innibos are Mpumalanga and Gauteng. At Oppikoppi, Gauteng is dominant. Free State is the variable that influences Volksblad.

\section{Relationship between Travelling Group and Days At Festival}

From the table below, it can be noted that both the travelling group and the number of days spent at the Festival are significant. The following tables will explain how significant: 
Table 6: ANOVA table

\begin{tabular}{|c|c|c|c|c|c|c|c|c|}
\hline \multirow[b]{2}{*}{ Variable } & \multicolumn{8}{|c|}{$\begin{array}{l}\text { Analysis of Variance } \\
\text { Marked effects are significant at } p<.05000\end{array}$} \\
\hline & $\begin{array}{l}\text { SS } \\
\text { Effect }\end{array}$ & $\begin{array}{l}\text { Df } \\
\text { Effect }\end{array}$ & $\begin{array}{l}\text { MS } \\
\text { Effect }\end{array}$ & $\begin{array}{l}\text { SS } \\
\text { Error }\end{array}$ & $\begin{array}{l}\text { Df } \\
\text { Error }\end{array}$ & $\begin{array}{l}\text { MS } \\
\text { Error }\end{array}$ & $\mathrm{F}$ & P \\
\hline $\begin{array}{l}\text { Travelling } \\
\text { group }\end{array}$ & 4896.239 & 2 & 2448.119 & 36389.25 & 1227 & 29.65709 & 82.54753 & 0.000000 \\
\hline $\begin{array}{l}\text { Days at } \\
\text { Festival }\end{array}$ & 58.714 & 2 & 29.357 & 2505.75 & 1227 & 2.04217 & 14.37539 & 0.000001 \\
\hline
\end{tabular}

Note: SS: Sum of squares

Df: Degrees of freedom

MS: Mean square

$F: F$ ratio

$P$ : $P$ value

\section{Relationship between Travelling Group and Festivals}

With reference to the table below, if the $d$ of the various Festivals is calculated, the following is the $d$ (where $d$ interprets the effect size of a variable on the different Festivals):

Between 1 and $2=0.79$ (medium to large)

Between 1 and $3=1.02$ (large)

Between 2 and $3=0.30$ (small to medium)

The difference in travelling group size between Oppikoppi and Innibos as well as that of Oppikoppi and Volksblad is large. Innibos and Volksblad do not differ significantly.

Table 7: Travelling group (Tukey HSD)

\begin{tabular}{|l|l|l|l|}
\hline \multirow{2}{*}{ Festival } & \multicolumn{3}{|l|}{$\begin{array}{l}\text { Unequal N HSD; Variable: Travelling group } \\
\text { Marked differences are significant at } \mathrm{p}<.05000\end{array}$} \\
\cline { 2 - 4 } & $\begin{array}{l}\{1\} \\
\mathrm{M}=8.7065\end{array}$ & $\begin{array}{l}\{2\} \\
\mathrm{M}=4.3865\end{array}$ & $\begin{array}{l}\{3\} \\
\mathrm{M}=2.7832\end{array}$ \\
\hline Oppikoppi $\{1\}$ & & 0.000022 & 0.000022 \\
\hline Innibos $\{2\}$ & 0.000022 & & 0.000048 \\
\hline Volksblad $\{3\}$ & 0.000022 & 0.000048 & \\
\hline
\end{tabular}

\section{Relationship between Days at Festival and Festivals Attended}

In Table 8 the different Festivals and the average number of days that attendants stayed, are measured.

Table 8: Days spend and festivals

\begin{tabular}{|l|l|l|l|}
\hline \multirow{4}{*}{ Festival } & \multicolumn{3}{|l|}{ Unequal N HSD; Variable: Days at Festival } \\
& Marked differences are significant at $\mathrm{p}<.05000$ & \\
\cline { 2 - 4 } & $\{1\}$ & $2\}$ & $\{3\}$ \\
& $\mathrm{M}=3.3881$ & $\mathrm{M}=2.8952$ & $\mathrm{M}=3.2987$ \\
\hline Oppikoppi $\{1\}$ & & 0.001487 & 0.805249 \\
\hline Innibos $\{2\}$ & 0.001487 & & 0.000076 \\
\hline Volksblad $\{3\}$ & 0.805249 & 0.000076 & \\
\hline
\end{tabular}

The results as captured in Table 8 can be explained as follows:

Between 1 and $2=0.35$ (small to medium) 
Between 1 and $3=0.06$ (small)

Between 2 and $3=0.28$ (small)

The difference in days spent at the Festivals is very small. This means that festinos stay at the Festivals for approximately the same number of days. The average is depicted in Table 8, column M (Mean).

Table 9: Expenditure at festivals

\begin{tabular}{|l|l|l|l|l|}
\hline Festival & $\begin{array}{l}\text { Number of } \\
\text { Observations }\end{array}$ & Variable & Mean & Maximum \\
\hline \multirow{5}{*}{ Innibos } & \multirow{2}{*}{577} & Spent on Food & 192.66 & 4000 \\
& & Spent on Alcohol & 154.29 & 10000 \\
& & Spent on Transport & 56.76 & 6000 \\
& Spent on Other & 659.78 & 10000 \\
\hline \multirow{3}{*}{ Oppikoppi } & \multirow{2}{*}{201} & Spent on Food & 293.98 & 2000 \\
& & Spent on Alcohol & 524.63 & 5000 \\
& & Spent on Transport & 258.91 & 1200 \\
Volksblad & \multirow{2}{*}{452} & Spent on Other & 590.00 & 900 \\
& & Spent on Food & 103.93 & 1800 \\
& & Spent on Alcohol & 98.66 & 3500 \\
& & Spent on Transport & 390.00 & 2900 \\
& Spent on Other & 0.00 & 0.00 \\
\hline
\end{tabular}

Table 9 shows the expenditure of tourists at the Festivals per person during the Festival. The mean (average) spend, as well as the maximum spending of tourists on certain sub-variables, is displayed. The average spent on food does not vary significantly from Festival to Festival. The amount spent on alcohol is, however, much higher at Oppikoppi than at the other two Festivals. The total spending at Innibos and Volksblad is higher than at Oppikoppi. The reason for this is that only one person filled out the questionnaire and, at the family Festivals (Innibos and Volksblad), the head of the family usually has to support the whole family whereas at Oppikoppi most of the festinos pay for themselves. Most of the visitor expenditure at Arts Festivals is on show tickets, food, accommodation, and souvenirs. It is evident that, on average, visitors spend almost twice the amount that locals spend at the Festivals (Saayman \& Saayman, 2004:638).

Days spent at the Festival do not differ significantly. The average Festival attendee stays for a period of three days. These results are however of little value if one does not indicate the implications of the findings. The latter will be dealt with in the next section.

\section{IMPLICATIONS OF FINDINGS}

Based on the results of this study, the following implications of the findings are eminent:

- There is no significant relationship between gender and the three Festivals, which implies that the marketing campaign does not have to distinguish between males and females. This, therefore, contradicts the work by Saayman and Saayman (2007) who found that female festinos attending the Klein Karoo National Arts Festival (South Africa's largest arts Festival) spend more than their male counterparts.

- Occupation as a variable differs from Festival to Festival and can be used for marketing purposes since Oppikoppi attracts more students and Innibos attracts more professionals, Volksblad on the other hand attracts a variety of students and professionals.

- Language shows a strong relationship and can therefore also be used as a segmentation variable and supports the findings of Dimara and Skuras (2003). 
- Province as a segmentation variable is also very significant and is seen as important from a marketing perspective. This finding supports the research conducted by Cannon and Ford (2002).

- Travelling group and days spent at the Festivals are also significant especially in the case of Oppikoppi. The lesson learnt with regard to the latter was in the composition of the Festival where festinos buy a package for the duration of the Festival. The implication is that it makes it more economically viable to stay longer.

- Expenditure at Festivals shows that visitors spend almost twice the mount spent by locals supporting research by Cannon and Ford (2002) and Saayman and Saayman (2007). Therefore, it is paramount that Festival organisers and marketers attract more visitors from outside the local area if the intention is to create a greater economic impact regionally.

\section{CONCLUSION}

The goal of this study was to examine market segmentation of visitors to three Arts Festivals in South Africa. The results indicate a variety of variables that can be used by Festival marketers to help develop a marketing strategy.

From the results gathered, it could be concluded that the average Volksblad and Innibos festinos differ primarily in terms of province of origin. Oppikoppi and Volksblad also have a few similarities - this could be because of Volksblad being held at Bloemfontein, which has a large student community, and because Oppikoppi also attracts mostly students. These tailor-made characteristics can assist marketers to develop effective marketing strategies, which could include product and service development, pricing and advertising.

The results show that gender and occupation have a medium to small effect on the Festivals, which implies there is no relationship between festinos and their gender or occupation.

Languages, the province from which festinos come, days spent at Festivals and travel group size all have a large effect on the Festivals. This means that the phi coefficient is higher than 0.5. The three Festivals under scrutiny are located in areas where Afrikaans is the language spoken by the majority. The provinces of the three Festivals generate a large number of attendants to the Festivals, which could mean one of two things. Firstly, that local marketing or word of mouth is effective; and secondly, that the festinos decide, on the spur of the moment, to attend the Festivals. From the results gathered above, it is clear that a large number of the attendants to the Festivals are local residents. This can be changed by means of improved marketing in neighbouring provinces.

The travel group size is larger for Oppikoppi than for Innibos and Volksblad. This information can be useful as students tend to travel in larger groups to save transport costs. Volksblad and Innibos seems to be Festivals that attracts families. This research contradicts some studies in this regard, but, as can be seen in the discussions, also supports a variety of other research projects.

From this research, it is recommended that a comparative study should be done with the larger Arts Festivals. Researchers could also conduct and analysis of the motives for attending these Festivals in greater depth as proposed by Lee, Lee and Wicks (2004:62).

\section{REFERENCES}

Bennet JA \& Strydom JW. 2001. Introduction to Travel and Tourism Marketing. Cape Town:Juta Education.

Bigne JE \& Andreu L. 2004. Emotions in segmentation: an empirical study. Annals of Tourism Research, 31(3):682-696.

Burke J \& Resnick B. 1999. Marketing and selling the travel product. $2^{\text {nd }}$ ed. Canada: Delmar. 
Cohen J. 1988. Statistical power analysis for behavioural sciences. $2^{\text {nd }}$ ed. Hillsdal, NJ: Erlbaum.

Cooper DR \& Emory CW. 1995. Business research methods. $5^{\text {th }}$ ed. Chicago: Irwin.

Cannon TF \& Ford J. 2002. Relationship of demographic and trip characteristics to visitor spending: an analysis of sports travel visitors across time. Tourism Economics, 8(3):263-71.

Dimara E \& Skuras D. 2003. Consumer evaluations of product certification, geographic association and traceability in Greece. European Journal of Marketing, 37(5/6):690-705.

Dibb S \& Simkin L. 2001. The marketing casebook: Cases and concepts. $2^{\text {nd }}$ ed. London: Thomson learning.

Ellis S \& Steyn HS. 2003. Practical significance (effect sizes) versus or in combination with statistical significance (P-values). Management Dynamic, 12(94):51-53.

Galloway G. 2002. Psychographic segmentation of park visitor markets: evidence for the utility of sensation seeking. Tourism Management, 23(6):581-596.

George R. 2004. Marketing South African Tourism. $2^{\text {nd }}$ ed. Cape Town: Oxford University Press.

Gursoy D, Kim K \& Uysal M. 2004. Perceived impacts of festivals and special events by organisers: an extension and validation. Tourism Management, 25(2):171-181.

Hauptfleisch T. 2001. The eventification of Afrikaans culture - some thoughts on the Klein Karoo National Kunstefees (KKNK). South African Theatre Journal, 15:169-177.

Hughes H. 2000. Arts, entertainment and tourism. Oxford: Butterworth-Heineman.

Innibos Festival. 2005. [Online] Available from: http://www.tjirp.net/innibos/ [Accessed: 02/06/2005].

Jang SC, Morrison AM \& O'Leary JT. 2002. Benefit segmentation of Japanese pleasure travellers to the USA and Canada: selecting target markets based on the profitability and risk of individual market segments. Tourism Management, 23:376-378.

Juaneda C \& Sastre F. 1999. Balearic island tourism: a case study in demographic segmentation. Tourism management, 20(4):549-552.

Kitshoff H. 2004. Claiming cultural festivals: Playing for power at the Klein Karoo Nasionale Kunstefees (KKNK). South African Theatre Journal, 18:65-81.

Koc E \& Altinay G. 2006. An analysis of seasonality in monthly per person tourist spending in Turkish inbound tourism form a market segmentation. Tourism Management, Available [online] 28 February.

Kotler P. 2003. Marketing Management. $11^{\text {th }}$ ed. New Jersey:Pearson Education Inc.

Kotler P \& Armstrong G. 2004. Principles of Marketing. $10^{\text {th }}$ ed. New Jersey:Pearson Education Inc.

Krejcie RV \& Morgan DW. 1970. Determining sample size for research activities. Educational and Psychological measurement, 30:607-610.

Lamb CW, Hair JF, McDaniel C, Boshoff C \& Terblanche NS. 2004. Marketing - second South African Edition. Cape Town: Oxford University Press. 
Lancaster G \& Reynolds P. 1999. Introduction to marketing: a step-by-step guide to all the tools of marketing. London: Daily Express.

Lee C, Lee Y \& Wicks BE. 2004. Segmentation of festivals: motivation by nationality and satisfaction. Tourism management, 25(1):61-70.

Lubbe B. 2000. Tourism distribution: managing the travel intermediary. Kenwyn: Juta \& co, Itd.

Marx S, Van Rooyen DC, Bosch JK \& Reynders HJJ. 1998. Business Management. $2^{\text {nd }}$ ed. Pretoria: Van Schaik Academic.

McDonald M \& Dunbar I. 1995. Market segmentation. Basingstoke :MacMillian Business.

McIntosh RW, Goelder CR \& Ritchie JRB. 1995. Tourism: Principles, Practices and Philosophies. $7^{\text {th }}$ ed. New York: Wiley.

Mok C \& Iverson TJ. 2000. Expenditure-based segmentation: Taiwanese tourists to Guam. Tourism management, 21(3):299-305.

Oppikoppi. 2005. Oppikopi website [Online] Available from: http://www.oppikoppi.co.za [Accessed: 22/08/2005].

Oppikoppi Bands. 2005. Oppikoppi Bands [Online] Available from: http://www.women24.com [Accessed: 06/10/2005].

Oppikoppi Information. 2005. Oppikoppi Information [Online] http://www.travelmax.statravel.co.uk/ [Accessed: 22/08/2005].

Saayman M. 2002. Hospitality, leisure and tourism management. Potchefstroom: Leisure Consultants and Publications.

Saayman M \& Saayman A. 2004. Economic impact of cultural events. South Africa Journal of Economic \& Management Sciences, 7(4):629-641.

Saayman M \& Saayman A. 2006. Marketing analysis of Aardklop National Arts Festival. Potchefstroom: Institute for Tourism and Leisure Studies.

Saayman M, Slabbert E \& Saayman A. 2005. Profile and economic impact of Volksblad arts festival. (Report on Profile and economic impact of Volksblad arts festival: 2005). Potchefstroom (Unpublished).

Saayman M \& Uys C. 2003. Profiling spectators at a one day international cricket match. Journal of Sports Tourism, 8(4):293.

Saayman M \& Saayman A. 2007. Socio-demographic and behavioural determinants of visitor spending at a National Arts Festival: a panel data analysis. World Journal on Events. (Waiting to be published)

Shaw MMT \& Leggat PA. 2003. Country profile: travelling to Australia. Travel Medicine and infectious disease, 1(2):126-133.

Silva J. 1998. The change, development and impact of the Grahamstown Arts Festival, with special reference to music. Grahamstown:Rhodes university (Unpublished Dissertation - M.A).

Slabbert E. 2002. Key success factors of tourism market segmentation. Potchefstroom: Potchefstroom University for CHE (Dissertation - M.A). 
Strydom AJ, Saayman M \& Saayman A. 2007. The Economic impact of the Volksblad Arts Festival. Acta Commercii, 6:87-98.

Steyn HS (jr.). 2000. Practical significance of the difference in means. Journal of industrial psychology, 26(3):1-3.

Snowball JD \& Willis KG. 2006. Estimating the marginal utility of different sections of an Arts Festival: the case of visitors to the South African National Arts Festival. Leisure Studies, 25(1):43-56.

Swarbrooke S. 2002. The development and management of Visitor attractions. $2^{\text {nd }}$ ed. Oxford: Butterworth-Heinemann Ltd.

Thrane C. 1997. Values as segmentation criteria in tourism research: the Norwegian monitor approach. Tourism management, 18(2):111-113.

Van Heerden A. 2002. Economic impact of the Aardklop National Arts Festival. Potchefstroom: Potchefstroom University for CHE (Dissertation - MCom).

Van Niekerk M \& Saayman M. 2004. Profile and economic impact of Innibos - Lowveld National Arts Festival. Tshwane University of Technology, Mpumalanga Campus and Potchefstroom Institute for tourism and leisure studies, Potchefstroom University.

Van Niekerk M \& Saayman M \& Saayman A. 2005. Profile and economic impact of Innibos Arts festival. Potchefstroom: Institute for Tourism and Leisure Studies.

Van Wyk H de J. 2004. Personal income - means of segmentation for the purposes of marketing research. South African Business review, 8(2):42-50.

Van Zyl C. 2005. Optimum market-positoining models for South African Arts festivals scenarios. University of South Africa (Thesis - DCom).

Van Zyl C. 2002. The participation of the host community in the Aardklop National Arts Festival. University of Pretoria (Dissertation - Mcom).

Van Zyl C \& Botha C. 2003. Motivational factors of local residents to attend the Aardklop National Arts Festival. Event Management, 8(4):213-222.

Visser G. 2005. Let's be Festive: exploratory notes on festival tourism in South Africa. Urban Forum, 16(3):155-175.

Volksbladfees. 2005. Volksbladfees. [Online] Available from: http://www.volksbladfees.co.za [Accessed: 25/08/2005].

Walpole MJ \& Goodwin HJ. 2000. Local economic impacts of Dragon Tourism in Indonesia. Annals of Tourism Research, 27(3):559-576.

Williams VE. 1997. The economic impact of the arts: a case study of the wealth and employment attendant on the Grahamstown National Arts Festival. Unpublished M.Com dissertation: Rhodes University, Grahamstown. 